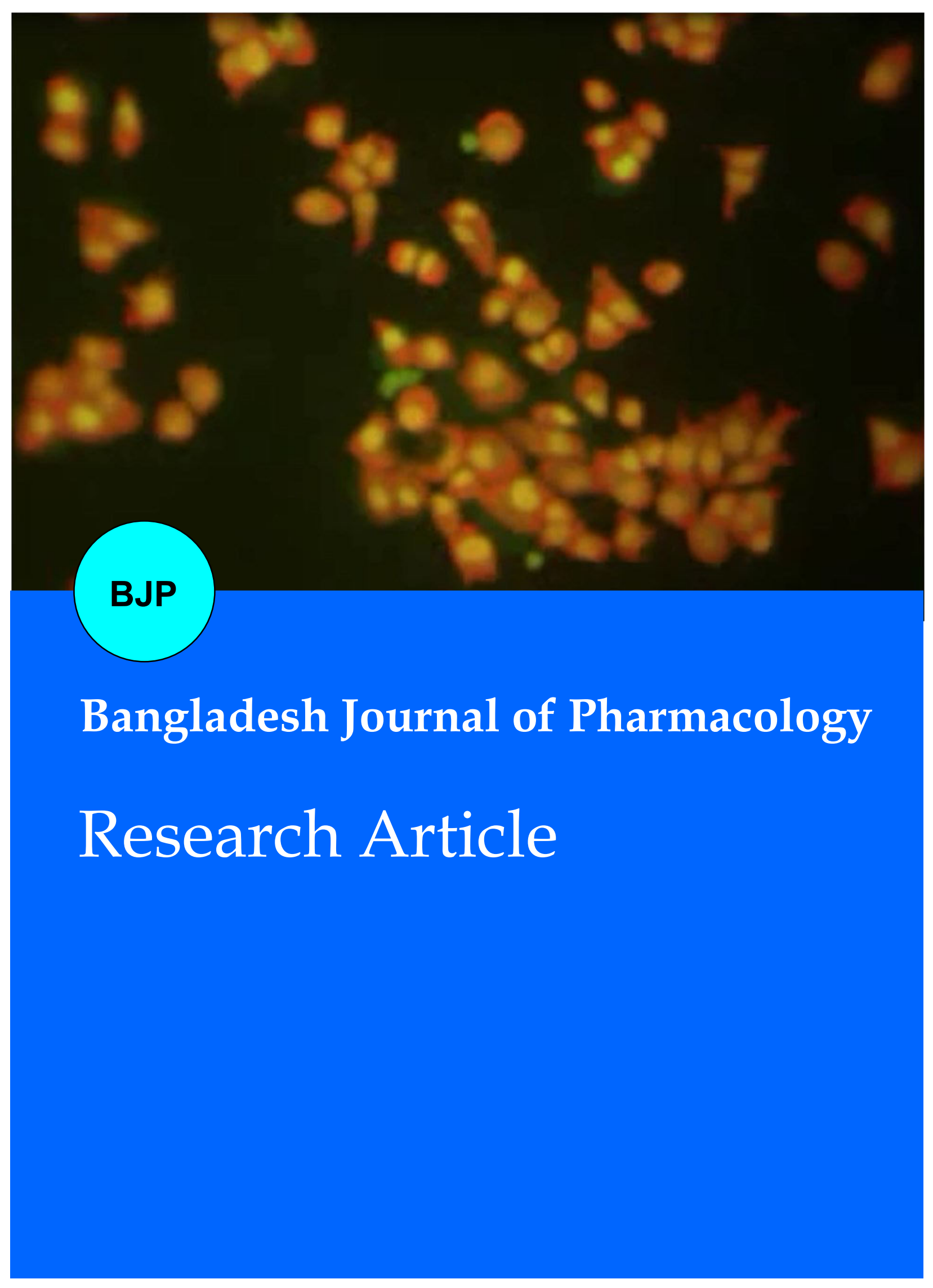




\title{
Anti-proliferative and apoptotic effects of quinine in human Hep-2 laryngeal cancer and KB oral cancer cell
}

\author{
Marimuthu Krishnaveni', Kathiresan Suresh² and Ramu Arunkumar² \\ ${ }^{1}$ Research and Development centre, Bharathiar University, Coimbatore, India; ${ }^{2}$ Department of Biochemistry and \\ Biotechnology, Faculty of Science, Annamalai University, Annamalai Nagar 608-002, Tamil Nadu, India.
}

\begin{tabular}{|c|c|}
\hline \multicolumn{2}{|l|}{ Article Info } \\
\hline Received: & 4 March 2016 \\
\hline Accepted: & 23 April 2016 \\
\hline Available Online: & 8 June 2016 \\
\hline \multicolumn{2}{|c|}{ DOI: 10.3329/bjp.v11i3.26961 } \\
\hline \multicolumn{2}{|c|}{$\begin{array}{l}\text { Cite this article: } \\
\text { Krishnaveni M, Suresh K, Arunkumar } \\
\text { R. Anti-proliferative and apoptotic } \\
\text { effects of quinine in human Hep-2 } \\
\text { laryngeal cancer and KB oral cancer } \\
\text { cell. Bangladesh J Pharmacol. 2016; 11: } \\
\text { 593-602. }\end{array}$} \\
\hline
\end{tabular}

\begin{abstract}
The present study evaluated the anti-proliferative and apoptotic effect of quinine on oral cancer cells Hep-2 and KB. Cell inhibition, apoptosis and antiinflammatory effects were explored by nuclear DNA cleavage, condensation, change in membrane potential of mitochondria. Meanwhile, inflammatory and apoptosis-related mRNA and proteins expressions such as iNOS COX-2, IL-6, Bcl-2, mutant p53, Bax, caspase-3 and NF-kB were determined by RTPCR and Western blotting assays. Results showed that, quinine treatment significantly inhibited the cell viability and colony formation, inhibited cell proliferation lead to increased generation of reactive oxygen species induction of MMP depolarization, morphological changes and DNA damage in doseand time-dependent manner. Moreover, quinine significantly decreased the iNOS, COX-2, IL-6, Bcl-2 and mutant p53 simultaneously up-regulated Bax, caspase-3 expressions through the inhibition of NF- $\mathrm{KB}$ suggest that quinine may serve as a potential candidate in the prevention of cell proliferation and enhances apoptosis via inhibiting up-stream signalling.
\end{abstract}

\section{Introduction}

Oral cancer is the $6^{\text {th }}$ most common cancer worldwide, reprising $48 \%$ of head and neck cancers (O'Callaghan et al., 2015). The dysregulation of inflammatory mediator's production including interleukin-6 (IL-6), Nitric oxide synthase 2, Prostaglandin-endoperoxide synthase 2 participate in oral squamous cell carcinoma (Ma et al., 2015; Lee et al., 2015). Hence, suppression of iNOS, COX-2, and IL-6 expression would produce a meaningful therapeutic response. Apart from inflammation p53, $\mathrm{Bcl}-2$, Bax and caspase- 3 are major mediators for proand anti-apoptotic mechanism that is essential for treatment with anti-cancer chemotherapies through apoptosis (Li et al., 2015; Bi et al., 2015). Each of these pro-inflammatory and anti-apoptotic genes were activated response of several transcription factors.

Nuclear factor- $\mathrm{kB}(\mathrm{NF}-\mathrm{kB} / \mathrm{Rel})$ is the most prominent transcription factor for modulation of inflammation and apoptosis (Yi et al., 2014; Khandelwal et al., 2011). Uncontrolled NF-kB subunits gain enter the nucleus and cause the synthesis of pro-inflammatory and antiapoptotic genes. Therefore, Nuclear factor kappa B gain attention in the treatment of several inflammatory diseases (Kim et al., 2013; Shou et al., 2002).

Quinine, natural alkaloid, has been isolated from the bark of the Rauvolfia caffra, that exhibits wide pharmaceutical activities like anti-pyretic, anti-inflammatory, anti-tumor and anti-malarial (Santos and Rao, 1998; Achan et al., 2011). No in vitro study has been done to evaluate the molecular mechanism and action of quinine on inflammatory and apoptotic gene. Therefore, the present work was aimed to determine the reduction in inflammation, programmed cell death potential of quinine in Hep-2 and KB cells. 


\section{Materials and Methods}

\section{Materials}

Quinine and Power SYBR® Green PCR master mix kit, protease inhibitor cocktail, bovine serum albumin, acrylamide, 2-mercaptoethanol, sodium dodecyl sulfate (SDS), $\mathrm{N}, \mathrm{N}, \mathrm{N}^{\prime}, \mathrm{N}^{\prime}$-tetramethylene diamine (TEMED), were purchased from Sigma Chemical Company (USA). Dulbecco's Modified Eagles Medium (DMEM), phosphate buffered saline, fetal bovine serum, $0.25 \%$ trypsin EDTA, antibiotics (penicillin, streptomycin), dimethyl sulfoxide, 2,7-diacetyl dichlorofluorescein (DCFH-DA), ethidium bromide, rhodamine 123, acridine orange, Hoechst 33342 stain were obtained from Hi-media Lab Ltd., India. The antibodies against p53, Bcl-2, Bax, and caspase-3 were purchased from Santa Cruz Biotechno$\operatorname{logy}$ (USA).

\section{Cell culture treatment}

Human laryngeal epithelial cancer cells (Hep-2 and KB) were bought from the National Center for Cell Science, Pune, India. Allow the cells to grow in Eagle's minimal essential medium augmented with Fetal bovine serum $10 \%$, with $100 \mu \mathrm{g} / \mathrm{mL}$ of pencillin- streptomycin. The cells were incubated at $37^{\circ} \mathrm{C}$ and at $5 \% \mathrm{CO}_{2}$ atmosphere.

\section{Reactive oxygen species (ROS) assessment}

Reactive oxygen species was assessed according to Rastogi et al, (2010). Probe used was 2,7-diacetyl dichlorofluorescein (DCFH-DA). Treat $8 \times 10^{6}$ cells (Hep2 and $\mathrm{KB}$ ) with $\mathrm{IC}_{50}$ concentration of quinine for 24 and 48 hours and made up to $2 \mathrm{~mL}$ using phosphate buffered saline ( $\mathrm{pH} 7.4$ ). To $1 \mathrm{~mL}$ of cells added $100 \mu \mathrm{L}$ of DCFH-DA $(10 \mu \mathrm{M})$, incubated for $30 \mathrm{~min}$ at $37^{\circ} \mathrm{C}$. Observe the cells under Nikon fluorescence microscope via blue filter at excitation and emission wavelength of $480 \mathrm{~nm}$ and $530 \mathrm{~nm}$.

\section{Change in membrane potential analysis of mitochon- dria}

Change in membrane potential of mitochondria was performed according to Scaduto and Grotyohann (1999). Culture $1 \times 10^{6}$ cells/mL (Hep2 , KB ) in a 6-well plate along with $\mathrm{IC}_{50}$ concentration of quinine for 24 and 48 hours. Control groups were maintained without quinine. Rhodamine 123 at $10 \mu \mathrm{M} / \mathrm{mL}$ was used to stain the cells and incubated at $5 \%$ atmospheric $\mathrm{CO}_{2}$ in a $\mathrm{CO}_{2}$ incubator for $30 \mathrm{~min}$. Wash the cells with phosphate buffered saline and observe using fluorescence microscope via blue filter.

\section{Programmed cell death assay by dual staining (Video Clip)}

Programmed cell death was assessed by the method of Lakshmi et al, (2008) using dual stain. Culture $5 \times 10^{3}$ cells in a 6-well plate with $\mathrm{IC}_{50}$ concentration of quinine for 24 and 48 hours. Control groups were treated similarly lacking quinine. The cultures were incubated at $5 \% \mathrm{CO}_{2}$ for 24 hours in a $\mathrm{CO}_{2}$ incubator. The cells were trypsinized, stained with acridine orange/ ethidium bromide (1:1), then washed with phosphate buffered saline and observe using blue filter at the magnification of 40x under fluorescence microscope.

\section{RT -PCR analysis for mRNA expression}

Total RNA was extracted from Hep and KB cells using RNeasy® Mini Kit (Qiagen, Germany). The RNA concentration determined using Nanodrop 2000 (Thermo Scientific, USA). $5 \mathrm{mg}$ of RNA was reversetranscribed to convert cDNA in a reaction mixture containing $4 \mathrm{~mL}$ of $5 \mathrm{x}$ reaction buffer, 20 units of RNase inhibitor, $2 \mathrm{~mL}$ of dNTPs mixture (10 mM), 200 units of avian-myeloblastosis virus (AMV) RT enzymes and $0.5 \mathrm{mg}$ of oligo (dT) primer sense and antisense primers (Sigma-Aldrich, USA) in a final volume of 20 $\mathrm{mL}$. The reaction mixture was incubated at $42^{\circ} \mathrm{C}$ for 60 min and the reaction was terminated by heating at $70^{\circ} \mathrm{C}$ for $10 \mathrm{~min}$. The cDNA was stored at $-80^{\circ} \mathrm{C}$ until further use. Gene expression was evaluated by PCR amplification using primer pairs based on published sequences. The amplification products were analyzed by electrophoresis using $2 \%$ of agarose gel containing ethidium bromide (EtBr). The PCR products were visualized as bands with a UV transilluminator and photographs were taken using gel documentation system.

\section{Western blotting}

SDS-PAGE was performed using equivalent protein extracts $(50 \mu \mathrm{g})$ from each sample. The resolved proteins were electrophoretically transferred to polyvinylidene difluoride membranes. The blots were incubated in $1 \times$ TBS containing $5 \%$ bovine serum albumin for 2 hours to block non-specific binding sites. The blot was incubated with 1:200 dilutions of primary antibodies overnight at $4^{\circ} \mathrm{C}$. After washing, the blots were incubated with 1:1000 dilution of horseradish peroxidase-conjugated secondary antibody for $45 \mathrm{~min}$ at room temperature. After extensive washes with high and low salt buffers, the immunoreactive proteins were visualized using DAB and enhanced chemiluminescence detection reagents.

\section{Statistical analysis}

Statistical analysis was performed using one-way analysis of variance (ANOVA) followed by Duncan's multiple range test (DMRT) by using Statistical Package of Social Science (SPSS) version 12.0 for windows. The values are mean \pm SD for six samples in each group. $p$ values $<0.05$ were considered as level of significance.

\section{Results}

\section{Generation of intracellular ROS}

The generation of ROS in Hep-2 and KB was studied in 
control as well as in treatment with quinine (Figure 1). The maximum of ROS generation was observed in the $\mathrm{IC}_{50}$ value of quinine among all doses.

\section{Mitochondrial membrane potential}

Changes of mitochondrial membrane potential in Hep-2 and $\mathrm{KB}$ cells were observed when treated with quinine

(Figures 2). Rhodamine 123 green fluorescence observed in cells with high membrane potential. Decrease in the fluorescence upon treatment with effective doses of quinine when compared to the untreated control cells evidenced apoptotic properties of quinine.

\section{Apoptotic morphological changes}

Figure 3 shows increased apoptotic cell deaths in Hep-2 and $\mathrm{KB}$ cells by treatment with quinine. The changes were determined by the color of DNA binding dyes acridine orange/ethidium bromide stain in individual cells. Live cells show bright green spots. The stained cells with $\mathrm{IC}_{50}$ concentration of quinine for 24 and 48 hours showed gradual increase in the apoptotic death (orange), whereas necrotic (red) cells were found.

\section{iNOS, COX-2, IL-6 and NF- $\kappa B$ production}

Figure 4 shows the effect of quinine on Hep-2 and KB cells (24 and 48 hours) against inflammation and apoptosis. iNOS, COX-2, IL-6 and NF- $\mathrm{KB}$ were hardly detected in control group. Treatment with quinine markedly attenuated expression of iNOS, COX-2, IL-6 and NF- $\mathrm{KB}$ by RT-PCR analysis, a marked reduction in both pro-inflammatory and transcription factors.

\section{Modulation of p53, Bcl-2, bax and caspase-3 expression}

To predict the quinine induces apoptosis, Western blot analysis to determine the protein expressions of mutant p53, bcl-2, bax and caspase-3 (Figure 5) in Hep-2 and KB cells at 24 and 48 hours. Quinine treatments significantly down-regulated anti-apoptotic mediator's mutant p53 and Bcl-2, at the same time up-regulated proapoptotic markers like caspsae- 3 and Bax protein expression in Hep-2 and $\mathrm{KB}$ cells as compared to control. Therefore, both RT-PCR and Western blot analysis result showed that quinine modulates the expression levels of inflammatory and apoptotic mediators expression near to normal.

\section{Discussion}

The present study clearly focuses on the natural alkaloid quinine against an imbalanced expression of proteins in cancer cells and correlating that regulation with clinical endpoints by molecular studies. Quinine treated with Hep-2 and KB cells showed reduced cell viability, MMP and increased ROS. In addition, quinine significantly prevented the altered expression of proinflammatory (iNOS, COX-2, IL-6), anti-apoptotic (Bcl-
2, p53) proteins and simultaneously recovered proapoptotic (Bax, caspase-3) genes expression via inhibition of the NF-kB nuclear translocation.

However, immoderate ROS levels with reduced cellular proliferation in the treated cells demonstrates that the cell death induced by quinine. Our result was supported by Liu et al., (2015). The analysis of the apoptotic phenomenon changed into similarly showed by the records of acridine orange/ethidium bromide staining. In our findings, treated cells showed fragmented apoptotic bodies in contrast to the large nucleus in untreated cells. The reduced mitochondrial membrane potential suggests apoptosis and assists to block cell death from necrosis (Baracca et al., 2003). Our findings also confirmed the reduced mitochondrial membrane potential when Hep-2 and KB cells were treated with quinine. Similar to our previous study (Krishnaveni and Suresh, 2015) above oxidative damage and morphological changes demonstrated that the drug might bring about mobile events signalling the apoptotic activity inside the cells within 48 hours of treatment.

Inhibition of inflammatory mediators are targeted to develop an effective strategy to prevent inflammatory diseases (Jung et al., 2015; Liu et al., 2014). The over expression of iNOS, COX-2 and IL-6 has been previously reported in head and neck squamous cell carcinoma as well as in many cancers to promote the inflammatory response (Jabłonska et al., 2006; Van Tubergen et al., 2011; Mohammad et al., 2011). Once activated by transcription factors these proinflammatory mediators produces high concentrations of NO and PEG-2 for a prolonged period of time (Kang et al., 2012). In the present study, Western blot analysis revealed that quinine was found to decrease inflammation through down-regulation of iNOS and significantly diminished COX-2 expression which could account for the protective role of quinine in Hep-2 and KB cells. IL-6, a pro-inflammatory cytokine associated with increased cancer cell proliferation and progression (Zhang et al., 2013). In fact, expression of IL-6 in the serum or tissue of patients with cancer correlates with poor prognosis (Bachelot et al., 2003). Quinine treatment effectively suppress pro-inflammatory cytokine interferon beta 2 synthesis which might be acting as a target to treat disorders linked with inflammation.

p53, a tumor suppressor controls cell proliferation and cell death by inducing apoptosis in response to various stresses (Mendoza Rodriguez and Ceron, 2001). However, overexpression of p53 mutant protein has been demonstrated in precancerous and cancerous lesions of the oral cavity (Lawall Mde and Crivelini, 2006). Our results were in line with these observations. Quinine treated Hep-2 and KB cells were found to decrease mutant p53 activity could account for the protective 


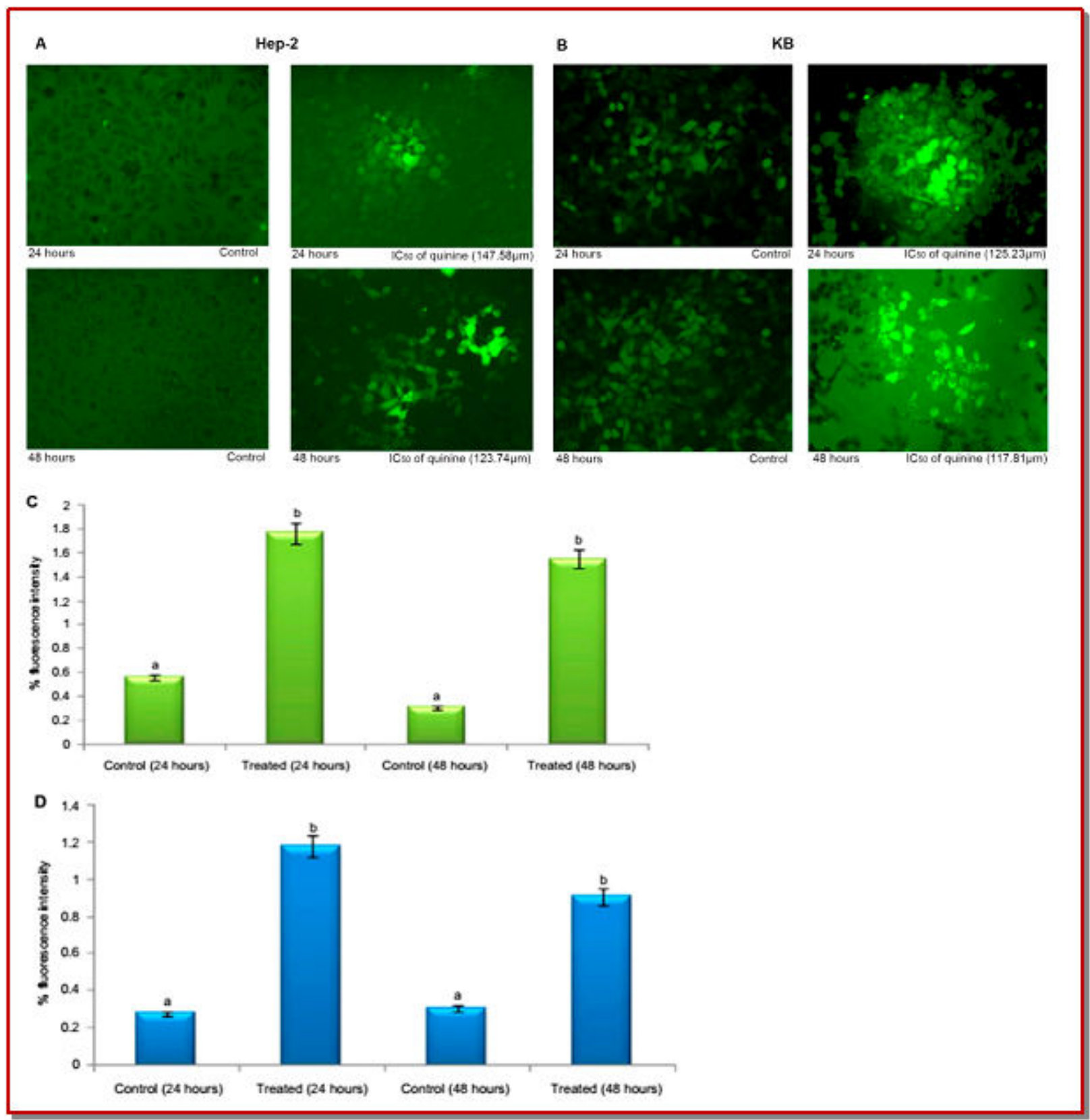

Figure 1: The levels of intracellular ROS in quinine treated (A) Hep-2 and (B) KB cells using DCFH-DA staining for 24 and 48 hours Hep-2 and KB cells were treated with IC50 concentration of quinine for 24 and 48 hours. Generation of ROS levels during quinine treated (C) Hep-2 and (D) KB cells was measured spectrofluorimetrically by DCFH-DA staining for 24 and 48 hours. Values are given as mean \pm SD differ significantly at $p<0.05 \mathrm{vs}$ control (DMRT)

role of natural alkaloid.

Bcl2, through complete cell survival, will make possible the acquirement of additional mutations in other oncogenes, tumor suppressor genes leading to clonal progression (Lee et al., 2007). Several studies pronounced that overexpression of Bcl-2 favors the cell towards abnormal proliferation through inhibiting proapoptotic genes activities. Caspases are critical enzymes that operate in apoptosis, in particular, caspase-3 activation is considered a convenient marker of apoptosis as it induces apoptosis via intinsic and extrinsic pathways. Caspase- 3 is essential for the amplification of caspases 8 and 9 which initiates disassembly either by means of extracellular signals or by releasing mitochondrial cytochrome c. Bax and caspase-3 deficiency or down-regulation has been reported in oral cancer and other kinds of cancer cells including Hep-2 and KB (Kochubei et al., 2015; Moon et al., 2013; Zhang et al., 2014). In the present study, quinine treatment to these oral cancer cells significantly triggers the induction of apoptosis with reduced Bcl-2, 


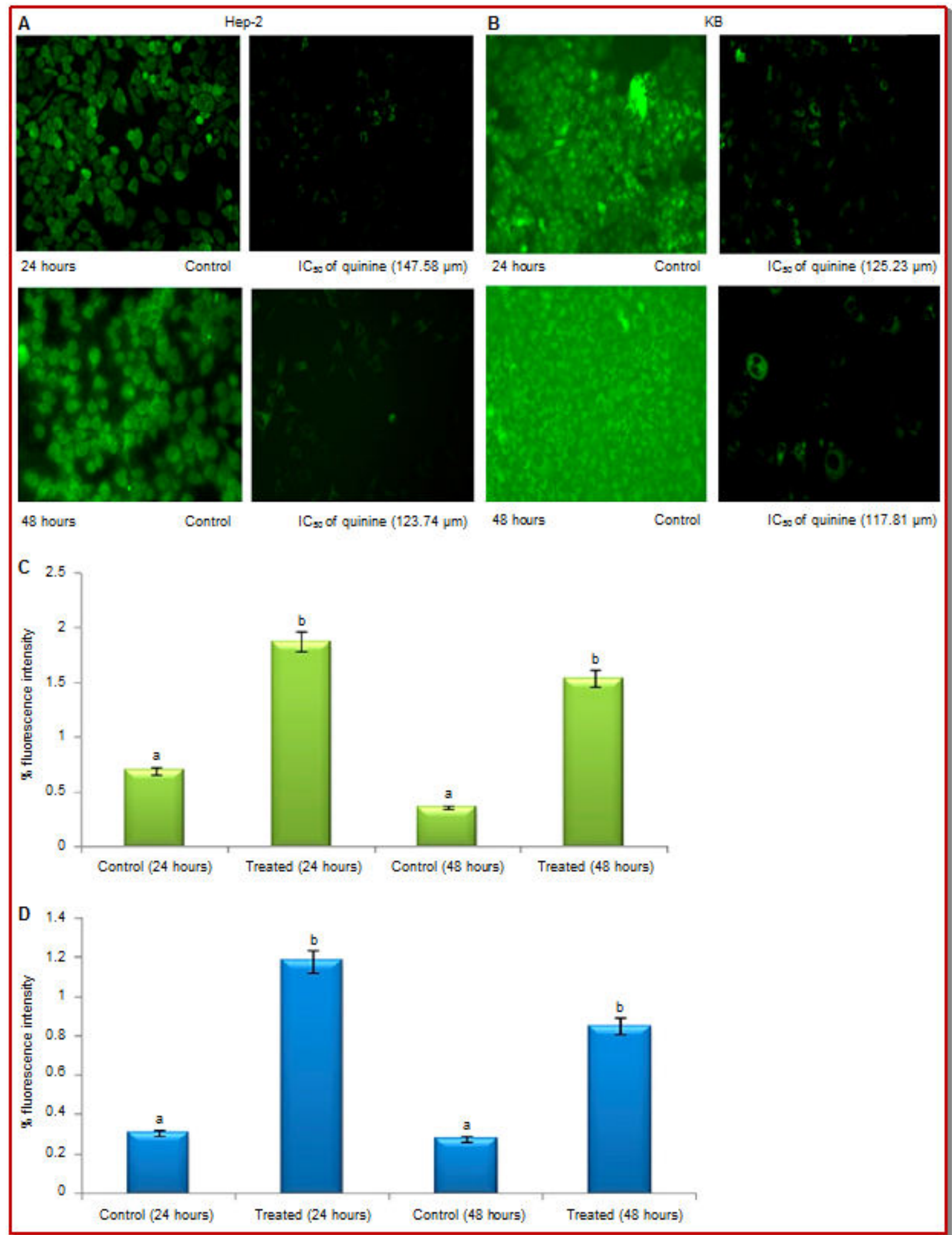

Figure 2: The effects of quinine on mitochondrial membrane potential in (A) Hep-2 and (B) KB cells were observed on rhodamine 123 stain in 24 and 48 hours treatments. (C) Hep-2 and (D) KB cells were treated with IC50 concentration of quinine for 24 and 48 hours. The reduction of mitochondrial membrane potential in quinine treated HEp-2 and KB cells was measured spectrofluorimetrically by rhodamine 123 staining for 24 and 48 hours. Value are given as mean $\pm S D$ differ significantly at $p<0.05$ vs. control (DMRT) 


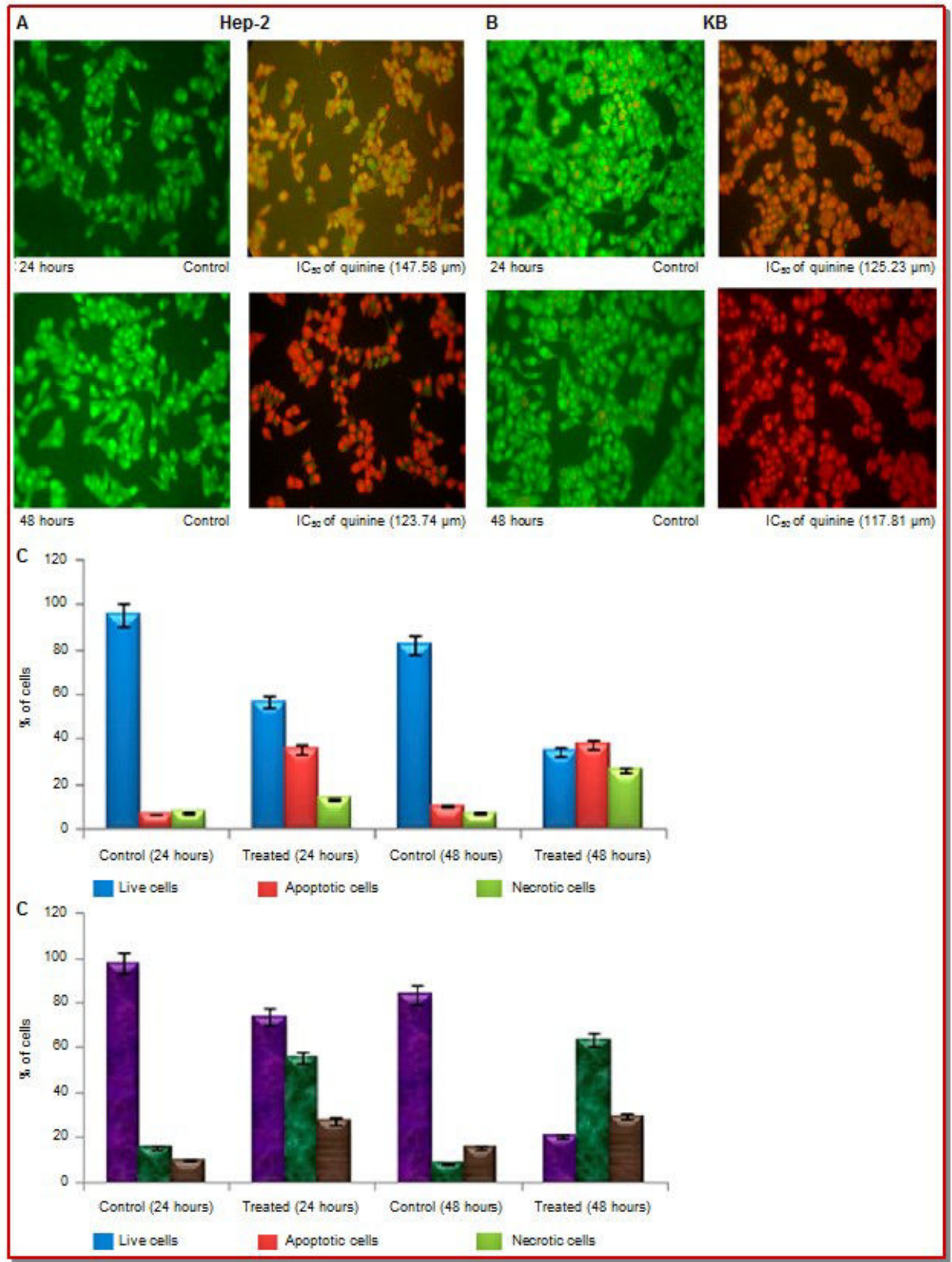

Figure 3: The effects of quinine on morphological changes in the (A) Hep-2 and (B) KB cells were observed on dual staining with $\mathrm{AO} / \mathrm{EBr}$ in 24 and 48 hours treatments. (C) Hep-2 and (D) KB cells were treated with IC50 concentration of quinine for 24 and 48 hours. The percentage of apoptotic cells were significantly increased compared with the control. The values are expressed as mean \pm SD from the six independent experiments $p<0.05$ 


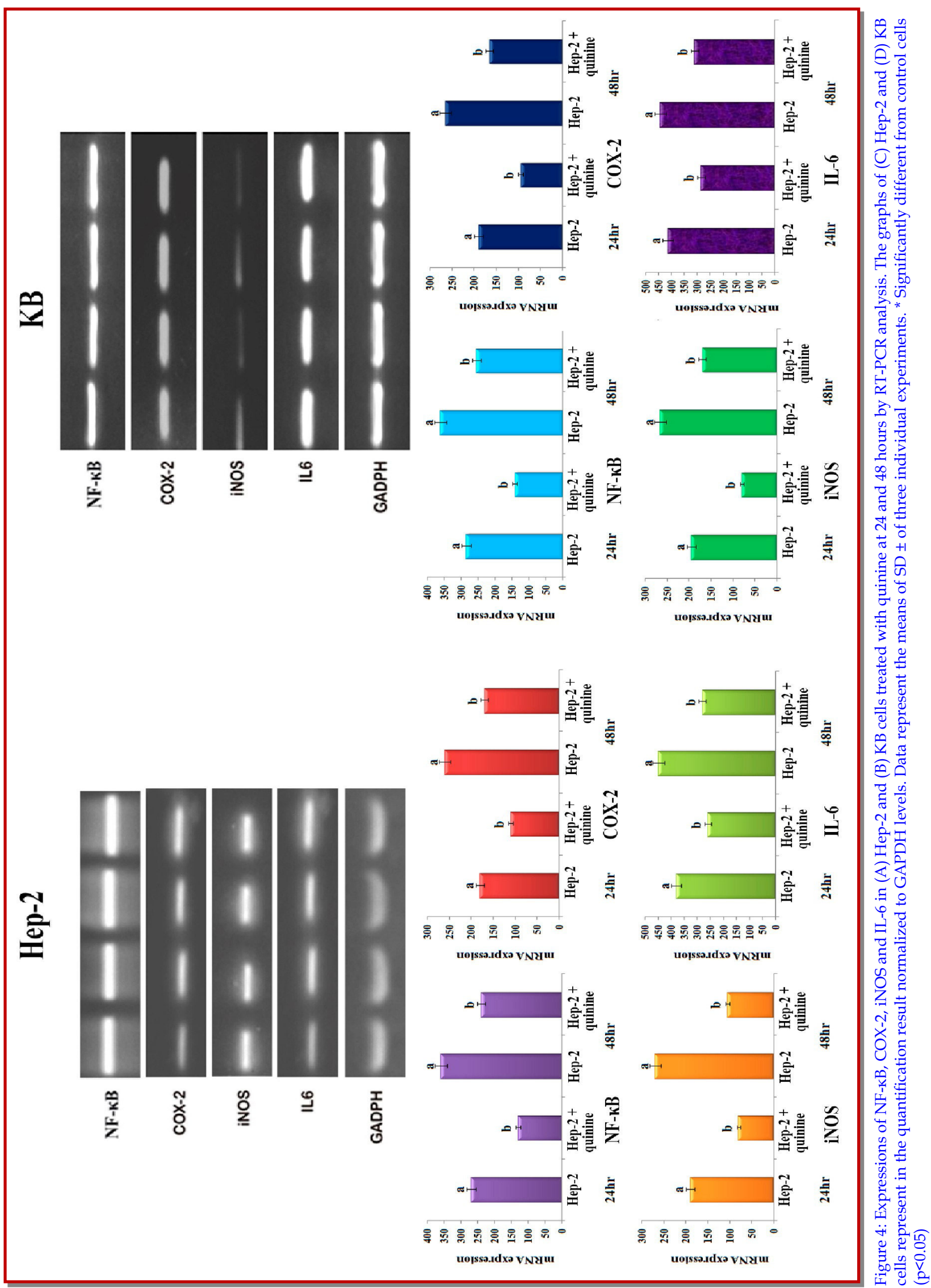




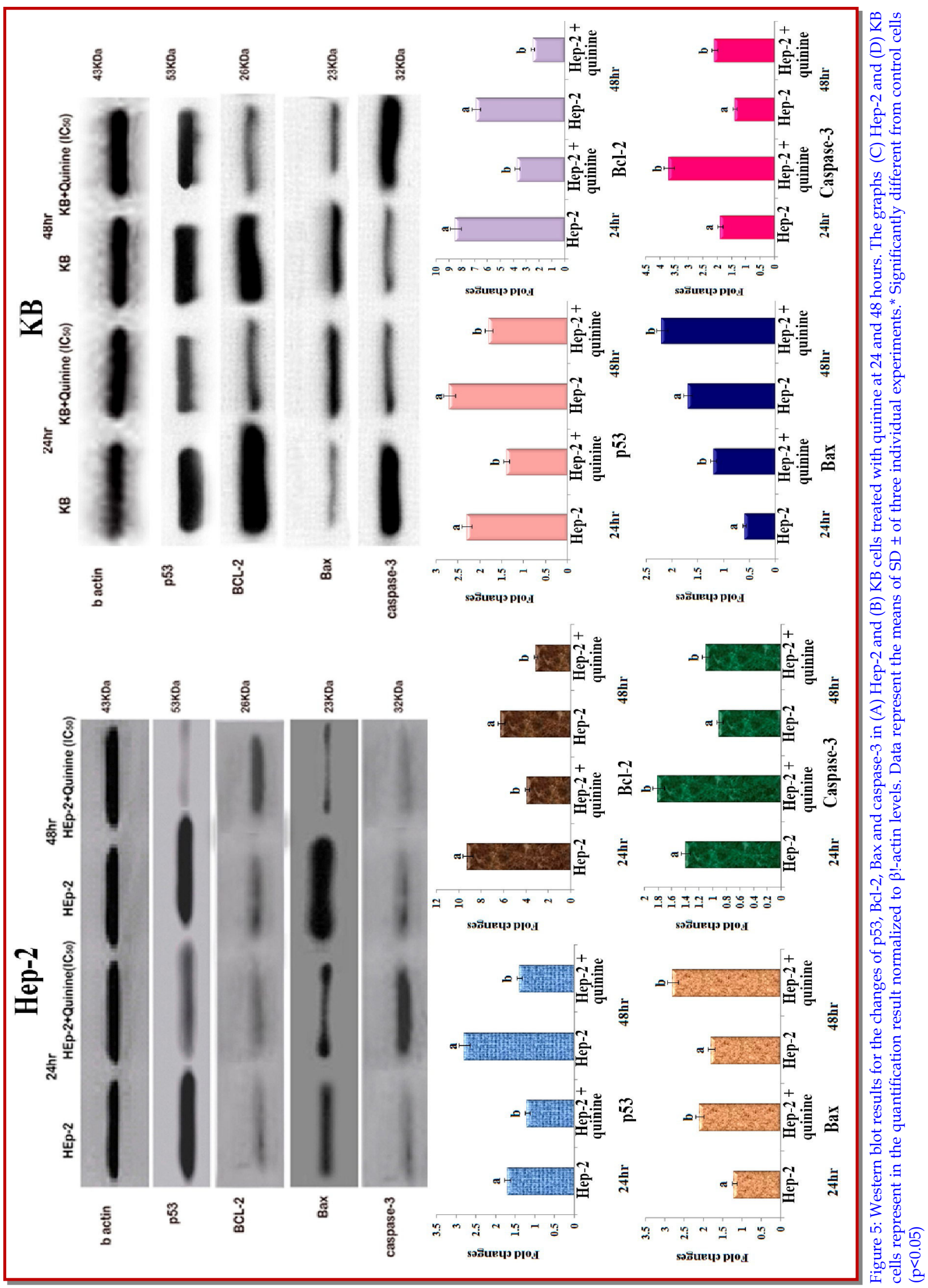


up-regulated Bax, caspase-3 expressions via inhibiting transcription factors activities.

NF- $\mathrm{KB}$ induces the expression of pro-inflammatory and anti-apoptotic mediators, transcription factors (Karin and Delhase, 2000). In NFkB cascade, cytokine activates IkB kinase complex-IKK. The activated IKK further stimulates the phosphorylation of IkBa, which subsequently allow its dissociation from NFkB, allowing translocation of $\mathrm{NFkB}$ to nucleus there by causing altered expression of gene. In the present study, there was an observed reduction in inflammatory mediators, anti-apoptotic $\mathrm{Bcl} 2$, mutant p53 and at the same time inducing caspase- 3 and $\mathrm{Bcl} 2$ associated $\mathrm{x}$ protein expression in Hep2, KB oral cancer cells which might be due to the inhibition of NFkB signaling.

\section{Conclusion}

Quinine showed potent anti-inflammatory and apoptotic effects through the inhibition of NF-kB, this could modulate the expression of pro-inflammatory and antiapoptotic mediators. Thus, quinine may provide a potential preventive candidate for inflammatory and apoptotic related disorders.

\section{Conflict of Interest}

This research has no conflict of interest.

\section{References}

Achan J, Talisuna AO, Erhart A, Yeka A, Tibenderana JK, Baliraine FN, Rosenthal PJ, D'Alessandro U. Quinine, an old anti-malarial drug in a modern world: Role in the treatment of malaria. Malar J. 2011; 10: 144.

Bachelot T, Ray-Coquard I, Menetrier-Caux C, Rastkha M, Duc A, Blay JY. Prognostic value of serum levels of interleukin 6 and of serum and plasma levels of vascular endothelial growth factor in hormone-refractory metastatic breast cancer patients. Br J Cancer. 2003; 88: 1721-26.

Baracca A, Sgarbi G, Solaini G, Lenaz G. Rhodamine 123 as a probe of mitochondrial membrane potential: Evaluation of proton flux through $\mathrm{F}(0)$ during ATP synthesis. Biochim Biophys Acta. 2003; 1606: 137-46.

Bi D, Yang M, Zhao X, Huang S. Effect of Cnidium lactone on serum mutant p53 and BCL-2/BAX expression in human prostate cancer cells PC-3 tumor-bearing BALB/C nude mouse model. Med Sci Monit. 2015; 21: 2421-27.

Jabłonska E, Puzewska W, Charkiewicz M. Effect of IL-18 on leukocyte expression of iNOS and phospho-IkB in patients with squamous cell carcinoma of the oral cavity. Neoplasma 2006; 53: 200-05.

Jung IH, Choi JH, Chung YY, Lim GL, Park YN, Park SW. Predominant activation of JAK/STAT3 pathway by interleukin-6 is implicated in hepatocarcinogenesis. Neoplasia 2015; 17: 586-97.
Kang J, Tae N, Min BS, Choe J, Lee JH. Malabaricone C suppresses lipopolysaccharide-induced inflammatory responses via inhibiting ROS-mediated Akt/IKK/NF-kB signaling in murine macrophages. Int Immunopharmacol. 2012; 14: 302-10.

Karin M, Delhase M. The I kappa B kinase (IKK) and NFkappa B: Key elements of pro-inflammatory signalling. Semin Immunol. 2000; 12: 85-98.

Khandelwal N, Simpson J, Taylor G, Rafique S, Whitehouse A, Hiscox J, Stark LA. Nucleolar NF-kB/RelA mediates apoptosis by causing cytoplasmic relocalization of nucleophosmin. Cell Death Differ. 2011; 18: 1889-903.

Kim DH, Chung JH, Yoon JS, Ha YM, Bae S, Lee EK, Jung KJ, Kim MS, Kim YJ, Kim MK, Chung HY. Ginsenoside Rd inhibits the expressions of iNOS and COX-2 by suppressing NF-kB in LPS-stimulated RAW264.7 cells and mouse liver. J Ginseng Res. 2013; 37: 54-63.

Kochubei TO, Maksymchuk OV, Piven OO, Lukash LL. Isolectins of phytohemagglutinin are able to induce apoptosis in HEp-2 carcinoma cells in vitro. Exp Oncol. 2015; 37: 116-19.

Krishnaveni M, Suresh K. Induction of apoptosis by quinine in human laryngeal carcinoma cell line (KB). Int J Curr Res Aca Rev. 2015; 3: 169-78.

Lakshmi S, Dhanaya GS, Joy B, Beena Joy, Padmaja G. Inhibitory effect of an extract of Curcuma zedoariae on human cervical carcinoma cells. Med Chem Res. 2008; 17: 335-44.

Lawall Mde A, Crivelini MM. PCNA and p53 expression in oral leukoplakia with different degrees of keratinization. J Appl Oral Sci. 2006; 14: 276-80.

Lee SH, Jeong EG, Yoo NJ, Lee SH. Mutational and expressional analysis of BNIP3, a pro-apoptotic Bcl-2 member, in gastric carcinomas. APMIS. 2007; 115: 1274-80.

Lee YY, Yang YP, Huang PI, Li WC, Huang MC, Kao CL, Chen YJ, Chen MT. Exercise suppresses COX-2 pro-inflammatory pathway in vestibular migraine. Brain Res Bull. 2015; 116: 98 105.

Li P, Zhao M, Parris AB, Feng X, Yang X. p53 is required for metformin-induced growth inhibition, senescence and apoptosis in breast cancer cells. Biochem Biophys Res Commun. 2015; 464: 1267-74.

Liu J, Guo W, Li J, Li X, Geng J, Chen Q, Gao J. Tumortargeting novel manganese complex induces ROS-mediated apoptotic and autophagic cancer cell death. Int J Mol Med. 2015; 35: 607-16.

Liu L, Li J, Kundu JK, Surh YJ. Piceatannol inhibits phorbol ester-induced expression of COX-2 and iNOS in HR-1 hairless mouse skin by blocking the activation of NF-kB and AP-1. Inflamm Res. 2014; 63: 1013-21.

Ma L, Pei H, Lei L, He L, Chen J, Liang X, Peng A, Ye H, Xiang M, Chen L. Structural exploration, synthesis and pharmacological evaluation of novel 5-benzylidene-thiazolidine-2, 4dione derivatives as iNOS inhibitors against inflammatory diseases. Eur J Med Chem. 2015; 92: 178-90.

Mendoza-Rodriguez CA, Ceron MA. Tumor suppressor gene p53: Mechanisms of action in cell proliferation and death. Rev Invest Clin. 2001; 53: 266-73. 
Mohammad S, Ram H, Gupta PN, Husain N, Bhatt ML. Overexpression of COX-2 in oral squamous cell carcinoma patients undergoing chemoradiotherapy. Natl J Maxillofac Surg. 2011; 2: 17-21.

Moon SM, Yun SJ, Kook JK, Kim HJ, Choi MS, Park BR, Kim SG, Kim BO, Lee SY, Ahn H, Chun HS, Kim do K, Kim CS. Anti-cancer activity of Saussurea lappa extract by apoptotic pathway in KB human oral cancer cells. Pharm Biol. 2013; 51: 1372-77.

O'Callaghan K, Palagano E, Butini S, Campiani G, Williams DC, Zisterer DM, O'Sullivan J. Induction of apoptosis in oral squamous carcinoma cells by pyrrolo-1,5-benzoxazepines. Mol Med Rep. 2015; 12: 3748-54.

Rastogi RP, Singh SP, Hader DP, Sinha RP. Detection of reactive oxygen species (ROS) by the oxidant-sensing probe $2^{\prime}, 7^{\prime}$-dichlorodihydro-fluorescein diacetate in the cyanobacterium Anabaena variabilis PCC 7937. Biochem Biophys Res Commun. 2010; 2397: 603-07.

Santos FA, Rao VS. A study of the anti-pyretic effect of quinine, an alkaloid effective against cerebral malaria, on fever induced by bacterial endotoxin and yeast in rats. J Pharm Pharmacol. 1998; 50: 225-29.

Scaduto RC, Grotyohann LW. Measurement of mitochondrial membrane potential using fluorescent rhodamine deriva- tives. Biophys J. 1999; 76: 469-77.

Shou Y, Li N, Li L, Borowitz JL, Isom GE. NF-kappaBmediated up-regulation of $\mathrm{Bcl}-\mathrm{X}(\mathrm{S})$ and $\mathrm{Bax}$ contributes to cytochrome $\mathrm{c}$ release in cyanide-induced apoptosis. J Neurochem. 2002; 81: 842-52.

Van Tubergen E, Vander Broek R, Lee J, Wolf G, Carey T, Bradford C, Prince M, Kirkwood KL, D'Silva NJ. Tristetraprolin regulates interleukin-6, which is correlated with tumor progression in patients with head and neck squamous cell carcinoma. Cancer 2011; 117: 2677-89.

Yi C, Zhang Y, Yu Z, Xiao Y, Wang J, Qiu H, Yu W, Tang R, Yuan $Y$, Guo W, Deng W. Melatonin enhances the antitumor effect of fisetin by inhibiting COX-2/iNOS and NFкB/p300 signaling pathways. PLoS One. 2014; 9: e99943.

Zhang H, Li X, Zhang Y, Luan X. Luteolin induces apoptosis by activating Fas signaling pathway at the receptor level in laryngeal squamous cell line Hep-2 cells. Eur Arch Otorhinolaryngol. 2014; 271: 1653-59.

Zhang Y, Yan W, Collins MA, Bednar F, Rakshit S, Zetter BR, Stanger BZ, Chung I, Rhim AD, di Magliano MP. Interleukin -6 is required for pancreatic cancer progression by promoting MAPK signaling activation and oxidative stress resistance. Cancer Res. 2013; 73: 6359-74. 


\section{Your feedback about this paper}

1. Number of times you have read this paper 0

2. Number of times you have seen the video clip 0

3. Quality of paper Click

4. Your comments

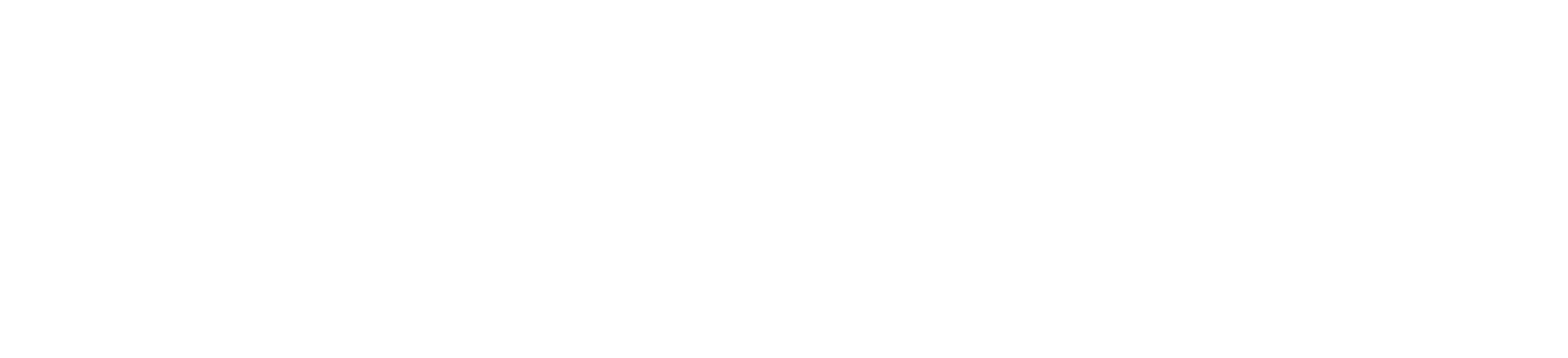

